\title{
The Role Of The Church To Press The Use Of Narcotics In Indonesia
}

\author{
Richard Saragih \\ \{detasco@yahoo.com\} \\ Postgraduate Program, Pelita Kebenaran School of Theology
}

\begin{abstract}
Even though narcotic-relatedcrimes have been classified as extreme crimes, narcotics abuse in Indonesia continues to increase. Distribution of narcotics increasingly implements varied methods and there is a large circulation network. The impact of narcotics abuse not only threatens users but also threatens the hinges of socio-economic life and future of the Indonesian people.Various efforts have been made by the government of the Republic of Indonesia to overcome narcotics abuse through legislation, i.e., establishing a National Narcotics Agency (BNN), establishing bilateral cooperation with other countries, education for public awareness and other efforts. The invlovement of the community, educational institutions and social institutions is needed to help the government overcome narcotics abuse. The spiritual approach is an important part of preventing the abuse of narcotics. The role of the church is very important to provide guidance for the congregation to avoid narcotics abuse through the values found in the Bible.
\end{abstract}

Keywords: Church, Narcotics

\section{Introduction}

Narcotics is a very serious problem among the young generation in Indonesia. The National Narcotics Agency (BNN) states that the dominant narcotics user is the young generation and the numbers are growing every year. Young people fall victims of narcotics and yet they are the future generation of the nation. Narcotics abuse is heavily affects health, society and economy of a nation. Other consequences of narcotics include diseases that can be transmitted through the lifestyle of addicts such as AIDS.

The high price narcotics compel addicts to commit crimes in order to fulfill their addictive reliance on narcotics. Thus impact of crime and social problems can damage the hinges of life, family and society for abusers. 
The President of the Republic of Indonesia Joko Widodo expressed his outrage about the problem of narcotics in Indonesia; he declared that the Republic of Indonesia is in the status of Narcotics Emergency.For the crimes that occur and the social problems that arise the church has a major opportunity and role to play in dealing with narcotics abuse among adolescents.

Table 1. Prevalence and narcotics abuse in 5 provinces, 2017

PREVALENCE AND NARCOTICS ABUSE FIGURES 5 PROVINCES IN INDONESIA 2017

\begin{tabular}{|c|c|c|c|c|}
\hline \multirow{2}{*}{ No. } & \multirow{2}{*}{ PROVINCE } & $\begin{array}{c}\text { Number of } \\
\text { Abusers }\end{array}$ & $\begin{array}{c}\text { Prevalence } \\
(\%)\end{array}$ & $\begin{array}{c}\text { Population } \\
(\mathbf{1 0}-59)\end{array}$ \\
\hline 1 & Jakarta & 260.656 & 3,34 & 7.800 .600 \\
\hline 2 & North Sumatera & 256.657 & 2,53 & 10.137 .500 \\
\hline 3 & East Borneo & 43.911 & 2,12 & 2.071 .436 \\
\hline 4 & Jambi & 53.177 & 2,02 & 2.626 .200 \\
\hline 5 & Mid Borneo & 38.981 & 1,98 & 1.967 .200 \\
\hline
\end{tabular}

Sourcer : Executive Summary Survey Narcotics Abuse Indonesia 2017

\section{INDONESIA IS IN STATUS OS NARCOTICS EMERGENCY}

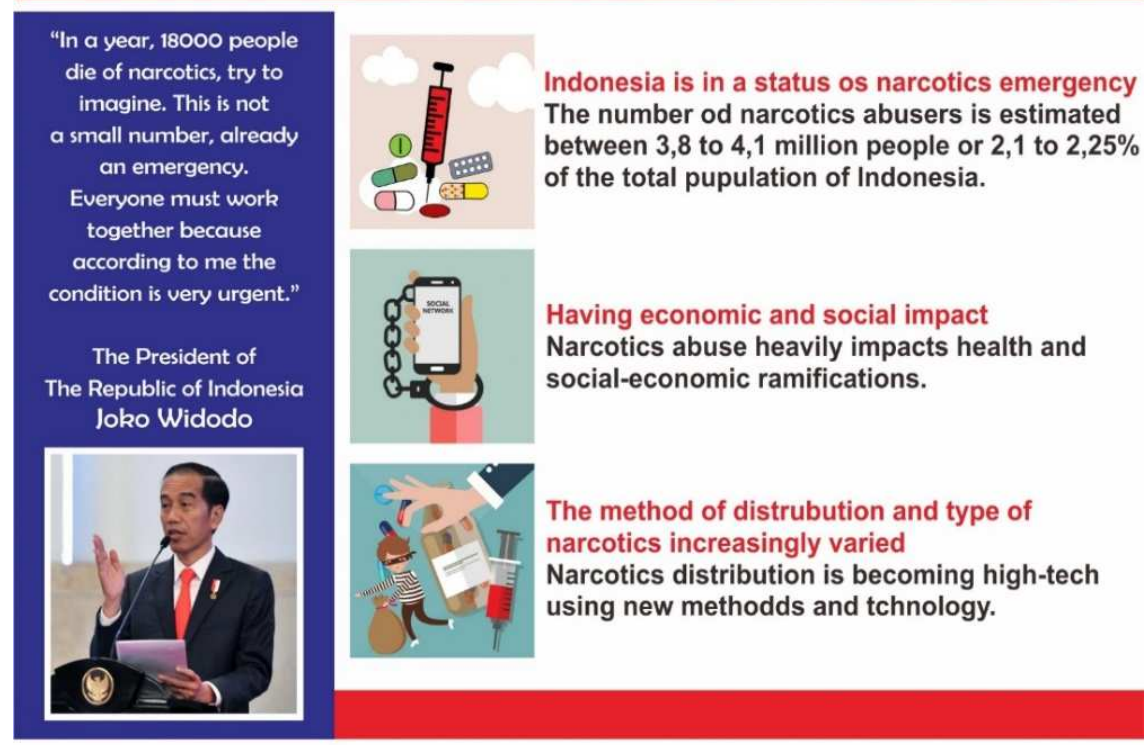

Statement by The President of The Republic of Indonesia regarding narcotics emergency

Based on the discussion in the introduction, the formulation of the problem is:

1. What are the dangers of Narcotics?

2. What is the church's view on narcotics?

3. What role can the church have overcoming narcotics abuse problem? 


\section{Method}

\subsection{Data Collection Method}

The data used in this paper is to document dataand literature study taken from the Republic of Indonesia National Narcotics Agency (BNN) website, news, bulletins and books.

\subsection{Direct Method}

Use direct methods and find information as references.

\section{Result and Discussion}

\subsection{Narcotics}

Narcotics can be defined as 'Substances or drugs derived from plants or not synthetic or semi-synthetic plants that can reduce or change consciousness, loss of pain and can cause dependence' (Regulation No. 35/2009 concerning narcotics).

\subsection{Causes Of Drug Users}

\subsubsection{Social environment}

- Motives a desire to know: in adolescence someone has curiosity, after that they want to try.

- The creation of opportunity: lack of attention from parents, lack of family affection or due to broken home.

- Facilities and infrastructure: parents provide chidren facilities and excessive money that enable children to afford drugs.

\subsubsection{Personality}

- Low self-esteem: feeling inferior in the community environment, narcotics as a way to overcome this problem.

- Emotional and mental: adolescence want to be detached from all the rules given by their parents. Eventually as an escape, they use using narcotics.

\subsection{Impact of Narcotics abuse}

\subsubsection{Physical}

- Disorders of the nervous system; convulsions, hallucinations, impaired consciousness, nerve damage.

- Disorders of the heart and blood vessels; acute heart infection circulatory disorders.

- Disorders of the lungs; suppression of respiratory function.

- Disorders of gastrointestinal hemopeotics, decreased reproductive system function, kidney failure, disorders of muscles and bones and the potential for contracting HIV-AIDS. 


\subsubsection{Psychological}

- Intoxitation (poisoning) symptoms where someone has felt the effects of (drunk) drug use.

- More doses to get the same effect after repeated use.

- Withdrawal Syndrome, addicts will be psychologically disturbed if they do not use it

- narcotics, known by addicts as sakau.

\subsubsection{Addiction (dependence)}

Circumstances where someone always needs certain substances (Addiction)

\subsubsection{Social Impact}

Various studies have proven that crime caused by Narcotics abuse can increase one's aggressive behavior both physically and psychologically.

\subsection{Church View Of Narcotics}

Reading the entire Bible, one cannot find a verse that discusses literally narcotics abuse, but implicitly it can be understood that God through His word is very appalled by abuse of narcotics.Christianity is known as a religion that greatly emphasizes love, so Christianity views narcotics as illegitimate goods, because there are elements that can damage nerve organs and the human body.Several Bible versescan be analyzed:

a. Corinthians 10:31 New King James Version (NKJV)

"Therefore, whether you eat or drink, or whatever you do, do all to the glory of God."

b. Ephesians 5:18 New King James Version (NKJV)

"And do not be drunk with wine, in which is dissipation; but be filled with the Spirit,"

c. Corinthians 6:19 New King James Version (NKJV)

"Or do you not know that your body is the temple of the Holy Spirit who is in you, whom you have from God, and you are not your own?"

Christians must be responsible for everything God entrusts to them; this includes the human body body. Narcotics use is aggressively damages health, physically, mentally, and emotionally. Many Bible verses forbid destructive actions. Thus according to the Bible, drug abuse is implicitly prohibited by God.

\subsection{The Church Role Overcome The Narcotics Abuse}

a. The church must teach what God desires and designs for human life and the church must show Christian living standards that glorify God.

b. The church must explain clearly the dangers of narcotics for the life of the congregation and its impact on the physical, psychological, social, and even spiritual.

c. The church must to build, support and strengthen Christian families and households so thay woud live their lives according to the principles of the word of God.

d. The church needs to provide pastoral care, counseling and mentoring for those indicated using drugs or are addicted to drugs. 


\section{Conclusion}

The church must educate the people what God desires and designs as the standard of living for Christians, displaying and imparting the quality of Christian life to the church.The church is identified by two parables or metaphors, namely as the "salt" and "light" of the world (Matthew 5: 13,14). Salt and light refer to the "difference" and "influence" that Christians must manifest to this world. The church must take part in resolving the problem of drug abuse in society.

\section{References}

[1] Badan Narkotika Nasional RI, 2017. Narkoba dan Permasalahannya. Jakarta: BNN RI

[2] Badan Narkotika Nasional RI, 2017. Pandangan Agama Kristen Tentang Bahaya

Penyalahgunaan Narkoba. Jakarta: BNN RI

[3] http://www.bnn.go.id. Web Site Badan Narkotika Nasional Republik Indonesia

[4] Sukiman, 2017. Keluarga Hebat Tanpa Narkoba. Jakarta: Kementerian Pendidikan dan Kebudayaan RI

[5] Indragiri, Reza. 2007. Psikologi Kaum Muda Pengguna Narkoba. Jakarta: Salemba Humanika

[6] http://www.gotquestions.org. Apa Kata Alkitab Mengenai Penyalahgunaan Narkotik

[7] Alkitab, Jakarta : Lembaga Alkitab Indonesia, 2014

[8] Sairin, Weinata. 2002. Visi Gereja Memasuki Milenium Baru. Jakarta: BPK. Gunung Mulia

[9] Oentoro, Jimmy. 2010. Gereja Impian. Menjadi Gereja yang Berpengaruh. Jakarta: Gramedia Pustaka Utama

[10] Indriati, Etty. 2006. Menulis Karya Ilmiah. Jakarta: Gramedia Pustaka Utama 